LWSA

PAPER - OPEN ACCESS

Analysis of Non Performing Financing (NPF), Financing to Deposit RATIO (FDR), Third Party Funds And Debt to Equity Ratio (DER) Murabahah of Funding in Indonesia

\author{
Author : Iskandar Muda \\ DOI $\quad: 10.32734 /$ lwsa.v1i1.152 \\ Electronic ISSN : :2654-7058 \\ Print ISSN : 2654-7066
}

Volume 1 Issue 1 - 2018 TALENTA Conference Series: Local Wisdom, Social and Arts

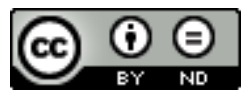

This work is licensed under a Creative Commons Attribution-NoDerivatives 4.0 International License.

Published under licence by TALENTA Publisher, Universitas Sumatera Utara
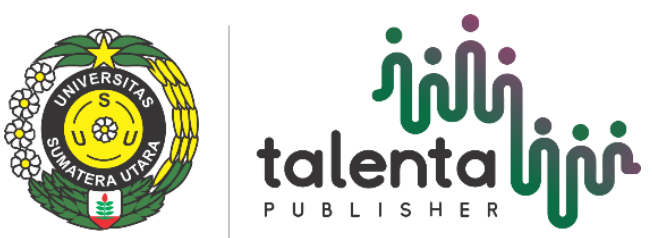


\title{
Analysis of Non Performing Financing (NPF), Financing to Deposit RATIO (FDR), Third Party Funds And Debt to Equity Ratio (DER) Murabahah of Funding in Indonesia
}

\author{
Iskandar Muda $^{\mathrm{a}}$, Nur Afifah $^{\mathrm{a}}$ \\ Faculty Economic and Business, University of Sumatera Utara, Medan-20155 \\ ismuda0507@yahoo.com
}

\begin{abstract}
This study was conducted to determine the effect of NPF, FDR, deposits, and DER to Islamic banking financing in Indonesia. This study uses the annual financial statements population of the entire Islamic Banks (BUS) in Indonesia in 2010-2014. The samples in this study using purposive sampling, that the sampling method using specific criteria. The amount of data used by 30 the annual financial statements of six Islamic banks which fulfill the criteria as a sample. The results showed that the NPF, FDR, deposits, and DER simultaneously affect the murabaha financing. The magnitude of the effect of the four independent variables against murabaha financing amounted to $95.9 \%$ and the remaining $4.1 \%$ is influenced by other variables outside of this study. For partial results, variable DPK and DER positive effect on murabaha financing. As for the variable FDR and NPF no significant effect on the murabahafinancing.
\end{abstract}

Keywords: Non-Performing Financing (NPF); Financing to Deposit Ratio (FDR); Third Party Funds (TPF); Debt to Equity Ratio (DER; Financing Murabaha.

\section{Introduction}

The Bank is a financial institution that is very important in running the economy and trade. Society developed and developing countries desperately need a bank as a place to conduct financial transactions and is a safe place to store funds for companies, governmental bodies, private or individual.Sharia banking is everything concerning the Sharia Bank and Sharia Business Unit, covering institutional, business activities, as well as the manner and process of carrying out its business activities (Law No.21 of 2008 concerning islamic banking). The rapid development of the system of Islamic banking in Indonesia at this time, especially in financial institutions, marked by the establishment of Bank Muamalat Indonesia in 1992.

Islamic banks are the banks that undergo its business activities based on Islamic principles and by type consisting of Islamic banks (BUS), sharia business unit (UUS), and the people of sharia bank financing (SRB). Growth and rapid development in the field of Islamic financial is of course also open opportunities for Indonesia to participate more actively in it. 
Table 1 : Total BUS, UUS and SRB in Indonesia in 1998-2014

\begin{tabular}{llllllllll}
\hline Year & 1998 & 2008 & 2009 & 2010 & 2011 & 2012 & 2013 & 2014 \\
\hline BUS & 1 & 5 & 6 & 11 & 11 & 11 & 11 & 12 \\
UUS & - & 27 & 25 & 23 & 24 & 24 & 23 & 22 \\
BPRS & 76 & 131 & 138 & 150 & 155 & 158 & 163 & 163 \\
\hline
\end{tabular}

Source: Sharia Banking Statistics (2014).

From the above table, the most widely distributed financing is murabaha by Islamic banks, proved from year to year murabaha financing continues to increase and more distributed than other financing. Murabaha financing assessed more easily and does not require sophisticated analysis as well as profitable.Karim (2004: 113) states that murabaha is a contract of sale of goods with stating that price acquisition and profit (margin) as agreed by the seller and the buyer. This contract is a natural form of certainty contracts, because in murabaha determined how much profit to be obtained.

Murabahah is a financing that positions the customer as a buyer and the bank as a seller, and this murabaha operational use pure harmony and terms of buying and selling, where there are several things that must be present in the sale and purchase transactions. There should be the perpetrators of the seller and the buyer, the object of purchase and the Islamic contract and agreement that accompanies the purchase agreement. Murabaha financing in Islamic banking is influenced by many factors, such as Non Performing Financing (NPF) Financing to Deposit Ratio (FDR), Third Party Funds and Debt to Equity Ratio (DER). This study was conducted to determine how much influence these variables against murabaha financing.

\section{Resarch Methodology}

\subsection{Type and source of data}

This type of research is associative causal, i.e research that analyze the relationship between one variable to another variable. The data used in this research is secondary data. This study uses annual data from the years 20102014 that were obtained from the website of each bank. This study uses a quantitative approach.

\subsection{Method of collecting data}

Data collection methods used in this research is the method of documentation, the method of collecting data to investigate and study the documents accordingly.

\subsection{Population and sample}

The population in this study is the annual financial statements of all BUS (Islamic Banks) in Indonesia in 20102014. The sampling used purposive sampling method, with the sampling criteria as follows:

a. Bank Syariah listed in BI in 2010-2014

b. Bank Syariah which publishes financial statements for 2010-2014 and has been published on the BI website or the website of each bank.

c. The annual financial statements have the completeness of the data used in this study.

\subsection{Research variable}

Dependent variable in this research is the Murabaha financing. While the independent variables in this study are:

a. Non Performing Financing (NPF) 

b. Financing to Deposit Ratio (FDR)
c. Third Party Fund (DPK)
d. Debt to Equity Ratio (DER)

\subsection{Data analysis method}

Descriptive Statistics analysis is a simple analysis method that aims to facilitate the interpretation and explanation of the analysis tables, graphs or diagrams.Before testing multiple regression, first performed classical assumption test consisting of normality test, multicoloniarity, heteroscedasticity and autocorrelation.Multiple Regression Analysis. Multiple regression analysis was used to measure the effect of NPF (X1), FDR (X2), DPK (X3) DER (X4) against murabaha financing $(\mathrm{Y})$ as the dependent variable.

\section{Result and Discussion}

Before performing the classic assumption test and multiple linear regression testing, first served descriptive statistics which can be seen in the following table :

Table 3 : Descriptive statistics

\begin{tabular}{lcllll}
\hline & LN_MURAB & DER & FDR & LN_DPK & NPF \\
\hline Mean & 29.26438 & 210.0483 & 87.37767 & 29.92906 & 2.923667 \\
Median & 29.51454 & 223.0800 & 89.12500 & 29.99827 & 2.990000 \\
Maximum & 31.14896 & 417.6000 & 102.7000 & 31.72238 & 6.840000 \\
Minimum & 25.40125 & 36.82000 & 68.92000 & 27.04544 & 0.100000 \\
Std. Dev. & 1.402349 & 101.3190 & 8.578692 & 1.269879 & 1.694117 \\
Observations & 30 & 30 & 30 & 30 & 30 \\
\hline
\end{tabular}

Source: Data processed

\subsection{Classical assumption method test}

\section{Normality test}

Normality test aims to test confounding or residual variable in the regression model that has a normal distribution or not. In this research,researchers used a statistic test analysis to determine whetherthe residual distributes normal or not.At the normality test this hypothesis is if the p-value $<0.1$ then H0is accepted meaning of datadistributed normally.

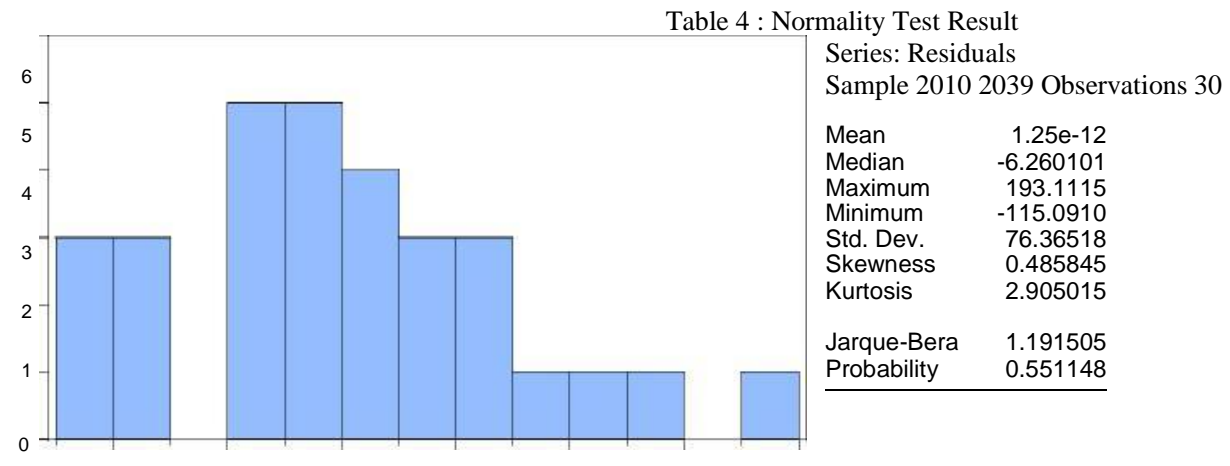

Source: Processed Data 
From data on Tabel4 can be said that theresidual data are normally distributed. This is reflected by the p-value> 0.05 which is equal to 0.551 .

\section{Multicoloniarity test}

Multicoloniarity test aims to test whether the regression model found a correlation between independent variables (independent). A good regression model is a regression model that does not corelate among the independent variables. To determine whether or not there is multicoloniarity if the correlation coefficient between each independent variable is greater than 0.8 then there is multicoloniarity in the regression model.

. Table 5 : Multicolinearity test

\begin{tabular}{|c|c|c|c|}
\hline DER & FDR & LN_DPK & NPF \\
\hline & 0.359767552845944 & 0.500585892624728 & 0.404406657920405 \\
\hline DER 1 & 5 & 4 & 6 \\
\hline FDR $\quad 0.359767552845944$ & 1 & 0.394578134552648 & 0.141207782151958 \\
\hline 5 & & 1 & 4 \\
\hline LN_DPK 0.500585892624728 & 0.394578134552648 & 1 & 0.672371717005831 \\
\hline 4 & 1 & & 4 \\
\hline NPF $\quad 0.404406657920405$ & 0.141207782151958 & 0.672371717005831 & 1 \\
\hline 6 & 4 & 4 & \\
\hline
\end{tabular}

Source: Processed Data

From Table 5 shows that the calculation results showed no independent variables taht has correlation coefficient value over 0.8 , so it can be concluded that multicolinearity does not occur in the regression model

\section{Heteroskedasticity test}

Heteroskedasticity test used to see whether a regression model variance occurs inequality. A good regression model does not haveheteroskedasticity. Heteroskedasticity test can be done with the whiteheteroskedasticity test. If the p-value obs * r-squared> 0.01 then $\mathrm{H} 0$ accepted, which means it does not have hetero skedasti city.

Table 6 : Heteroscedasticity test

Heteroskedasticity Test: White

\begin{tabular}{llll}
\hline F-statistic & 2.709549 & Prob. F(4,25) & 0.0530 \\
Obs*R-squared & 9.072606 & Prob. Chi-Square(4) & 0.0593 \\
Scaled explained SS & 6.001197 & Prob. Chi-Square(4) & 0.1991
\end{tabular}

Source: Data processed

Based on Table 6 shows that the p-value of $0.0593>0.01$ then $\mathrm{H} 0$ is accepted. This means with the $90 \%$ confidence level can be said there no heteroscedasticity occurs in the regression model.

\section{Autocorrelation test}

Autocorrelation test aims whether in a linear regression model there is a correlation between intruder error in period $t$ with intruder error in period $t-1$ (previous one). Autocorrelation problems arise because successive observation at all times in relation to each other. This condition is often found in the time series data (time series) for their "interference" in individual or group which is likely to affect "interference" in individual or group in the next period. If the $\mathrm{p}$-value obs * r-squared $>0.01$ then $\mathrm{H} 0$ is accepted which means no auto correlation 
Table 7 : Autocorrelation Test Results

Breusch-Godfrey Serial Correlation LM Test:

\begin{tabular}{lll}
\hline F-statistic & 0.133019 Prob. F(2,23) & 0.8761 \\
Obs*R-squared & 0.343038 Prob. Chi-Square(2) & 0.8424 \\
\hline
\end{tabular}

Source: Processed Data

Table 7 shows that the $\mathrm{p}$-value obs * $\mathrm{r}$-squared $0.8424>0.01 \mathrm{It}$ is concluded that there is no autocorrelation in the data.

\section{Hypothesis testing}

This study uses multiple regression analysis in data processing. This analysis uses statistical test $\mathrm{t}$ and $\mathrm{F}$ statistical test using a significance level of $5 \%$ or 0.05 . If the level of significancy less than 0.05 , the $\mathrm{H} 1$ is accepted, whereas the significance level is greater than 0.05 then $\mathrm{H} 0$ is accepted.

\section{Simultaneous Significance Tests (Statistic F)}

FTest shows all the independent variables in the regression model have a simultaneous effect on the dependent variable. If the significance value $<0.05$, H5 accepted. Effect of simultaneous Non Performing Financing (NPF), Financing to Deposit Ratio (FDR), Third Party Fund (DPK and Debt to Equity Ratio (DER) to Murabahah can be seen in Table 8

Table 8 : Simultaneous Significance Test (F Statistic Test)

\begin{tabular}{lrll}
\hline R-squared & 0.965126 & Mean dependent var & 29.26438 \\
\hline Adjusted R-squared & 0.959546 & S.D. dependent var & 1.402349 \\
S.E. of regression & 0.282058 & Akaike info criterion & 0.457606 \\
Sum squared resid & 1.988922 & Schwarz criterion & 0.691138 \\
Log likelihood & -1.864084 & Hannan-Quinn criter. & 0.532315 \\
F-statistic & 172.9642 & Durbin-Watson stat & 2.136509 \\
Prob(F-statistic) & 0.000000 & & \\
\hline
\end{tabular}

Source: Processed Data

The results ofdata processing in Table 8 through prob (F-statistic) shows that the significance value of 0.000 $<0.05$. The probabilitytest value is less than 0.05 indicates regression model can be used simultaneosly to predict Murabahah. This proves that Non Performing Financing (NPF), Financing to Deposit Ratio (FDR), Third Party Fund (DPK and Debt to Equity Ratio (DER) simultaneously affect positively on murabaha. It is concluded that H5 is accepted in the model of thisregression study.

\section{Individual Parameter Significance Test (t Statistic Test)}

$\mathrm{T}$ statistic test used to determine the effect of each independent variable to explain dependent variable with a significance level of $5 \%$ or 0.05 . If the probability value $<0.05$, the regression coefficient is significant and $\mathrm{H} 1, \mathrm{H} 2$, $\mathrm{H} 3$, and $\mathrm{H} 4$ are accepted

Table 9 : Individual Parameter Significance Test (t Statistic Test) Dependent Variable: LN_MURABAHAH

\begin{tabular}{cccccc}
\hline Variable & Coefficient & Std. Error & t-Statistic & Prob. \\
\hline LN_DPK & 0.973669 & 0.062799 & 15.50442 & 0.0000 \\
FDR & 0.006966 & 0.006941 & 1.003481 & 0.3252 & 0.0226 \\
DER & 0.001500 & 0.000617 & 2.431014 & 0.5118 \\
NPF & 0.028589 & 0.042958 & 0.665507 & -0.531896 & 0.5995 \\
C & -0.883813 & 1.661628 & & \\
\hline
\end{tabular}

Source: Processed Data 
Based on $\mathrm{t}$ test results In Table 9 it appears that:

- NPF has a significance number of 0.512 , because the value of thesignificance $t$ test is greater than 0.05 , H1is not accepted so that no significant difference between the NPF and murabaha financing.

- FDR has a significancenumber of 0.325 , because the value of thesignificance $t$ test is greater than 0.05 , the $\mathrm{H} 2$ is rejected so that no significant difference between FDR and murabaha financing.

- DPK has a significance figure of 0.000 , due to the significant value of the $t$ test is less than 0.05 , the H3 is accepted so that there is a significant difference between the DPK and murabaha financing.

- DER has a number of significance of $0.023, \mathrm{t}$ test for significance value is less than 0.05 then the H4 is accepted so that there is a significant influence between DER and murabaha financing.

\section{Coefficient of Determination}

The coefficient of determinationTest $\left(\mathrm{R}^{2}\right)$ is used to measure how far the ability of the model to explain variations in the dependent variable. The coefficient of determination between 0 and 1 . If the value of determination coefficient close to one, then the independent variables provide almost all the information required to predict the dependent variable. This study uses the coefficient of determination using the adjusted R-square value for evaluating the regression model. Adjusted R-square value in the study can be seen in Table 10 below.

Table 10 : The coefficient of determination (Adjusted R2)

\begin{tabular}{lrll}
\hline R-squared & 0.965126 & Mean dependent var & 29.26438 \\
\hline Adjusted R-squared & 0.959546 & S.D. dependent var & 1.402349 \\
S.E. of regression & 0.282058 & Akaike info criterion & 0.457606 \\
Sum squared resid & 1.988922 & Schwarz criterion & 0.691138 \\
Log likelihood & -1.864084 & Hannan-Quinn criter. & 0.532315 \\
F-statistic & 172.9642 & Durbin-Watson stat & 2.136509 \\
Prob(F-statistic) & 0.000000 & & \\
\hline
\end{tabular}

Source: Processed Data

From Table 10 it can be seen that the magnitude of the adjusted R-square of 0.959 or $95.9 \%$. Halini means 95.9\%. The dependent variable ofmurabahacan be significantly explained by variations in the independent variables. While the rest of $4.1 \%(100 \%-95.9 \%)$ is explained by other variables outside the regression model in this study.

\section{Multiple Regression Analysis}

Murabahah $=-0,884+0,029 \mathrm{NPF}+0,007 \mathrm{FDR}+0,974 \mathrm{DPK}+0,002 \mathrm{DER}+\varepsilon$

Coefficients in the regression equation above can be interpreted as follows:

1) Based on t test resu If everything on the independent variables is considered as constant, then the value of murabaha financing amounted to -0.884 .

2) Variable NPF has a positive regression coefficient of 0.029 .

3) Variable FDR has a positive regression coefficient of 0.007.

4) The DPK quality variable has a positive regression coefficient of 0.974 .

1) The variable of Debt to Equity Ratio (DER) has a positive regression coefficient of 0.002 .

\section{Discussion}

\section{Effect of Non Performing Financing (NPF) against Murabahah}

Hypothesis test results showed that the variables of Non Performing Financing (NPF) did not significantly affect the variable of Murabaha that is seen from the level of significance $0.512<0.05$. Variable of Non Performing Financing (NPF) has a positive regression coefficient of 0.029. Non Performing Financing (NPF) is the risk of nonpayment of financing provided by Islamic banks. The high levelNPF leads bank to experiencing difficulties and the downgrading of the bank, so the bank is expected to maintain a reasonable range of NPF in the rate set by the central 
bank that is a minimum of 5\%. If the NPF levels above 5\% then the bank be more cautious and reduced funding channeled.The results are consistent withPratimi research (2011) which states that the NPF did not have a significant effect on the financing murabaha that allegedly NPF Islamic banks are relatively small compared to conventional banks so it is not a major consideration in offering financing, because the previous Islamic banks to select customers with the precautionary principle. In addition, if the NPF increase indicates that the murabaha financing also increased because the financing that is already in the customer hands become its responsibility in terms of returns.

\section{Effect of Financing to Deposit Ratio (FDR) against Murabahah}

Hypothesis test results showed that the variables of Financing to Deposit Ratio (FDR) did not significantly affect the Murabahah variables that can be seen from a significance level of $0.325>0.05$. The variable quality of the FDR has a positive regression coefficient of 0.007. This is in line with Nurbaya research (2013) which states that FDR did not affect the murabaha financing.In Rimadani and Erza Research Journal (2011) conducted on Sharia Bank Mandiri said that the Financing to Deposit Ratio (FDR) had no significant effect on the growth of the bank's murabaha financing Syariah Mandiri. This indicates that the low effectiveness of intermediation function of BSM shown by the low of FDR did not affect the financing.

\section{Effect of Third Party Fund (DPK) against Murabahah}

Hypothesis test results indicate that the positive effect of DPK variable to variable Murabaha is seen from the level of significance $0.000<0.05$. It is said to have a positive influence for DPK variable as it has a positive regression coefficient of 0.974 . This means that the third party funding affects murabaha. If the DPK has increased the murabaha financing disbursed will also increase and vice versa, if DPK decreased the murabaha financing also decreased. DPK is one of the financial resources owned by a bank to carry out financing activities. By having a high DPK then the bank has a substantial financial resources to conduct the distribution of funds. This is in line with research conducted by Nurjaya (2011), namely DPK has a positive effect on murabaha financing, Nurbayaresearch (2013) states that DPK has a positive and significant effect on the financing murabaha.

Lifstin research journal (2014) which states that the DPK has a positive impact on the murabahafinancing If DPK has increased the murabaha financing disbursed will also increase and vice versa.Qolby Research Journal (2013) states that the relationship between the Third Party Funds (TPF), with Islamic banking financing is positive. The positive relationship is because the third party fund is the major funding sources in Islamic banking, the greater the number of third-party funds collected by the Islamic banking, then the greater the financing will be provided by the islamic banking to society. From several journals and these studies can be interpreted that the higher DPK value the higher Coefficients in the regression equation above can be interpreted as follows:murabaha financing which can be issued by a bank. This is because the higher the funds received from third-party bank, the more funds can also be processed and issued by the bank in terms of financing.

\section{Effect of Debt to Equity Ratio (DER) of the Murabahah}

Hypothesis test results showed that the variable of DER has a positive effect on the Murabahavariable which is seen from the level of significance $0.023<0.05$. It is said to has a positive influence as the DERvariable has a positive regression coefficient of 0.002. This means that the Debt to Equity Ratio affects murabaha. This is in line with the research conducted by Yanis (2013) which states that partially DER has a positive effect on the murabahafinancing This may imply that the higher theDER value the higher murabaha financing which can be issued by a bank.

\section{Effect of Non Performing Financing (NPF), Financing to Deposit Ratio (FDR), Third Party Fund (DPK and Debt to Equity Ratio (DER) of the Murabahah.}

Hypothesis test results showed that all independent variables i.e Non Performing Financing (NPF), Financing to Deposit Ratio (FDR), Third Party Fund (DPK and Debt to Equity Ratio (DER) simultaneously affect Murabahah. This can be seen from the probability value is less than 0.05 amounted to 0.000 . This shows that if one of the independent variable does not exist, it can reduce Murabahah 


\section{Conclusion}

This study examines whether the Non Performing Financing (NPF), Financing to Deposit Ratio (FDR), Third Party Funds, and Debt to Equity Ratio have significant effect on the Murabahafinancing in Islamic banking in Indonesia. The sample in this study amounted to 30 samples with 5 years of observations from 2010 to 2014. Based on the analysis and test research hypotheses in the previous chapter, the conclusion that can be drawn from this study is as follows:

1. After testing the hypothesis can be concluded that in partial Non Performing Financing (NPF) is not significant to murabaha financing. The results are consistent with Pratimi research (2011) which states that the NPF did not have a significant effect on the murabaha financing.

2. Financing to Deposit Ratio (FDR) is not significant to murabaha financing, in accordance with the results of this study and Erza Rimadani Research Journal (2011) conducted on Sharia Mandiri Bank said that the Financing to Deposit Ratio (FDR) had no significant effect on the growth of murabaha financing,

3. Third Party Fund (DPK) affects positively and significantly on the financing murabaha. The results are consistent with Lifstin research (2014) which states that the DPK positively influences murabaha financing. Qolby Research Journal (2013) states that the relationship between the Third Party Funds (TPF), and Islamic banking financing is positive. Nurjaya Research (2011) and Nurbaya (2013) states that DPK affects positively and significantly on murabaha financing

4. Debt to Equity Ratio (DER) affects positively and significantly on the murabaha financing. This is in line with research conducted by Yanis (2013) which states that DER in partial affects positively on murabaha financing

5. It can be concluded also that the variable of Non Performing Financing (NPF), Financing to Deposit Ratio (FDR), Third Party Funds, and Debt to Equity Ratio simultaneously affects positively on murabaha financing.

6. The test results of coefficient of determination $\left(\mathrm{R}^{2}\right)$, the amount of $\mathrm{R}$ square $\left(\mathrm{R}^{2}\right)$ obtained was 0,959. Thus the magnitude influence exerted by Non Performing Financing (NPF), Financing to Deposit Ratio (FDR), Third Party Funds, and Debt to Equity Ratio variables on murabaha financing amounted to $95.9 \%$, while the remaining $4.1 \%$ is affected by other variables not examined in this study

\section{References}

[1] Badruzaman, Najahi. "Analisis Pengaruh DPK, Tingkat Bagi Hasil, SWBI Terhadap Pembiayaan pada Bank Syariah di Indonesia", Skripsi Sarjana Fakultas Ekonomi dan Ilmu Sosial UIN Syarif Hidayatullah, Jakarta,2009.

[2] Erlina dan Sri Mulyani, 2007. Metodologi Penelitian Bisnis untuk Akuntansi dan Manajemen, Cetakan Pertama, USU Press, Medan.

[3] Fatimah, Iim. "Pengaruh Penempatan SBIS dan Pasar Uang antar Bank Berdasarkan Prinsip Syariah terhadap FDR Perbankan Syariah". Skripsi Sarjana Fakultas Ekonomi dan Bisnis, Universitas Islam Negeri Syarif Hidayatullah, Jakarta, 2008.

[4] Ghafur. 2007. "Pengaruh Rasio Keuangan Bank terhadap Pembiayaan Bank Syariah".

[5] Ghozali, Imam. 2006. Aplikasi Analisis Multivariate dengan Program SPSS. Cetakan V. Semarang: UNDIP.

[6] Ismail. 2011. Perbankan Syariah Edisi I, Kencana Prenada Media Group, Jakarta.

[7] Karim, Adiwarman. 2004. Bank Islam: Analisis Fiqih dan Keuangan". Raja Grafindo Persada. Jakarta. Maftuhin, Arif. 2004, Menyoal Bank Syariah, Paramadina, Jakarta.

[8] Maula, Khodijah Hadiyyatul. "Pengaruh Simpanan (dana pihak ketiga), Modal Sendiri, Margin Keuntungan dan NPF terhadap Pembiayaan Murabahah pada Bank Syariah Mandiri", Skripsi Sarjana Fakultas Syariah Universitas Sunan Kalijaga, Yogyakarta, 2008.

[9] Muhammad. 2006. Bank Syariah, Analisis Kekuatan, Peluang dan Ancaman, Edisi 2, Penerbit Ekonisia, Yogyakarta.

[10] Muhammad. 2014. Manajemen Keuangan Syariah, Edisi I, UPP STIM YKPN, Yogyakarta. Muhammad. 2002. Pengantar Akuntansi Syariah, Salemba Empat, Jakarta

[11] Nurbaya, Ferial. “Analisis Pengaruh CAR, ROA, FDR, Dana Pihak Ketiga terhadap pembiayaan Murabahah Periode 2001 -2009 (studi kasus pada bank Muamalat”, skripsi Sarjana Fakultas Ekonomi, Universitas Diponegoro, Semarang, 2013. 
[12] Nurjaya, Endang. "Analisis Pengaruh Inflasi, SBIS, NPF, dan DPK terhadap Pembiayaan Murabahah pada Bank Syariah di Indonesia". Skripsi Sarjana FEB, Universitas Islam Negeri Syarif Hidayatullah, Jakarta, 2011.

[13] Prastanto. "Faktor Yang Mempengaruhi Pembiayaan Murabahah Pada Bank Umum Syariah di Indonesia:, Universitas Negeri Semarang, 2012.

[14] Pratimi, Dwi Arianti.2011. "Analisis Pengaruh DPK, CAR, NPF dan ROA terhadap Pembiayaan Bank Umum Syariah".

[15] Pratin dan Akhyar. 2005. Analisis Hubungan Simpanan, Modal Sendiri, NPL, Presentasi Bagi Hasil dan Mark Up keuntungan Terhadap Pembiayaan pada Perbankan Syariah. Jurnal ISSN: 1410-9018 hal 35-52.

[16] Qolby, Muhammad Luthfi. 2013. "Faktor-Faktor yang Mempengaruhi Pembiayaan pada Bank Syariah di Indonesia periode 2007-2013". Economic Development Analysis Journal. UNNES.

[17] Ramadani, Mustika. “Analisis Variabel-variabel yang Mempengaruhi Pembiayaan Murabahah pada Bank Syariah Mandiri periode 20082011" Fakultas TrisaktiUniversitas Trisakti, Jakarta, 2011.

[18] Rimadani dan Erza. 2011. "Analisis Variabel-Variabel yang Mempengaruhi Pembiayaan Murabahah pada Bank Syariah Mandiri periode 2008-2011. Jurnal Media Ekonomi Vol 19 No.1.

[19] Ruslim. “Analisis Pengaruh CAR, NPL, LDR, ROA pada Bank Umum Syariah yang Terdaftar di Bank Indonesia” Fakultas Ekonomi dan Bisnis Universitas Hasanuddin, Makassar, 2012.

[20] Salman, Kautsar Rizal. 2012. Akuntansi Perbankan Syariah, Akademia Permata, Jakarta.

[21] Sudarsono, Heri. 2003. Bank dan Lembaga Keuangan Syariah, Penerbit Ekonisia, Yogyakarta.

[22] UU No.10 Tahun 1998 Tentang Perbankan

[23] UU No.21 Tahun 2008 Tentang Perbankan Syariah

[24] Yanis, Ahmad Samhan. "Faktor-faktor yang Mempengaruhi Pembiayaan Murabahah pada Perbankan Syariah do Indonesia". Sekolah Tinggi Ilmu Ekonomi Indonesia, 2011.

[25] Yuhan. "Pengaruh Kurs, Inflasi, DPK, SWBI dan Pendapatan Bank terhadap tingkat pengguliran dana bank syariah" . Skripsi Fakultas Ekonomi dan Bisnis Universitas Dian Nuswantoro, Semarang, 2014. 